\title{
Three Strategies for the Design of Advanced High-Entropy Alloys
}

\author{
Ming-Hung Tsai \\ Department of Materials Science and Engineering, National Chung Hsing University, Taichung 40227, Taiwan; \\ mhtsai@nchu.edu.tw; Tel.: +886-4-2284-0500 (ext. 303) \\ Academic Editors: An-Chou Yeh and Kevin H. Knuth \\ Received: 4 May 2016; Accepted: 4 July 2016; Published: 15 July 2016

\begin{abstract}
High-entropy alloys (HEAs) have recently become a vibrant field of study in the metallic materials area. In the early years, the design of HEAs was more of an exploratory nature. The selection of compositions was somewhat arbitrary, and there was typically no specific goal to be achieved in the design. Very recently, however, the development of HEAs has gradually entered a different stage. Unlike the early alloys, HEAs developed nowadays are usually designed to meet clear goals, and have carefully chosen components, deliberately introduced multiple phases, and tailored microstructures. These alloys are referred to as advanced HEAs. In this paper, the progress in advanced HEAs is briefly reviewed. The design strategies for these materials are examined and are classified into three categories. Representative works in each category are presented. Finally, important issues and future directions in the development of advanced HEAs are pointed out and discussed.
\end{abstract}

Keywords: high-entropy alloy; alloy design; second phase

\section{Introduction}

The concept of high-entropy alloys (HEAs) was proposed by Yeh et al. in 2004 [1]. It refers to a class of alloys that is composed of five or more principal elements, whose concentrations fall in the range of 5-35 at.\% [1]. Some researchers adopt a different definition based directly on entropy, which considers alloys with configurational entropies higher than $1.5 \mathrm{R}$ (where $\mathrm{R}$ is the gas constant) as HEAs [2,3]. Due to their multi-principal-element nature, HEAs possess four unique core effects $[4,5]$ : high entropy, sluggish diffusion [6], severe lattice distortion, and cocktail effects.

In the past decade, significant attention has been paid to these materials mainly due to two reasons. Firstly, the concept of HEAs brings a whole new perspective and unprecedented opportunities to metallic materials. The conventional view of the alloy world is based on dozens of individual alloy families such as Ti alloys, $\mathrm{Cu}$ alloys, etc. This is because conventionally there has to be a solvent element for each alloy. The baseless concept in HEAs frees metallurgists from this constraint and opens up a new dimension (instead of just a few new alloy systems) in alloy design. Therefore, the invention of HEA has been referred to as "a renaissance in physical metallurgy" [7]. Secondly, many reported HEAs have exciting properties, for example, high strength and toughness, good wear/corrosion resistance, high structural thermal stability, good resistance to thermal softening, and special electric or magnetic properties. It is worth mentioning that these properties were typically obtained without careful optimization of composition and/or microstructure. Therefore, it is anticipated that the properties of these materials can be further improved once related knowledge is developed.

Probably owing to the compositional complexity and the intimidating amount of possible element combinations, initial studies on HEAs largely focused on HEAs composed of common metallic elements, particularly $\mathrm{Al}, \mathrm{Co}, \mathrm{Cr}, \mathrm{Cu}, \mathrm{Fe}$, and $\mathrm{Ni}$. This leads to the two classic alloys systems that have been most extensively studied: Al-Co-Cr-Cu-Fe-Ni [8-22] and Al-Co-Cr-Fe-Ni [23-28]. The crystal structure, phase transformation, microstructure, mechanical properties of these systems have been 
reported in detail, and the evolution of the above issues with respect to the content of each element have also been investigated. Considerable effort has also been devoted to the derivative systems of these classic systems. A system is said to be "derived" from another if the number of different principal element between the two is two or less [5]. Researchers usually either replace one of the elements with a different element, or simply add other element into the classic systems. For example, derivative systems alloyed with Mo, Mn, Si, B, Zr, Ni, Nb, V, Y, Sn, Zn, C [29-38] have been reported. These early results provided important understanding of the composition-phase-property relationship in HEAs, which made composition design and phase control possible to certain extent. Despite the important contributions of the early studies, these studies are largely of an exploratory nature. For example, the composing elements of the early alloys are usually very similar. Although there can be one or two uncommon alloying elements, they are selected more or less arbitrarily. Additionally, the ratio of the elements are usually either equimolar or mostly equimolar (only one of the elements have varying content). Most importantly, there is no specific goal to be achieved in the design of the early alloys.

Very recently, the development of HEAs has gradually entered a different stage. Unlike the early alloys, HEAs studied nowadays are usually designed to meet clear goals, and have carefully chosen composing elements, deliberately introduced multiple phases, and tailored microstructures. These alloys will henceforth be referred to as advanced HEAs. In this paper, the design strategies of advanced HEAs are examined, and they can be classified into three categories. The progress within each category is then reviewed. The three categories are: (1) application-based redesign; (2) enhancing the entropy of conventional alloys; and (3) incorporating second phases.

It should be noted that the three strategies are not mutually exclusive. In other words, an alloy can be designed using more than one of the above strategies at the same time. This will be further explained later. It should be also noted that some of the alloy systems discussed in this paper (e.g., some high-entropy steels and brasses) are not HEAs by definition. However, because they are directly inspired by the high-entropy concept, these alloys are also discussed in the present paper.

\section{Application-Based Redesigning}

Application-based redesign is probably the most prevalent strategy of the three. It aims to design HEAs for a particular application. The selection of component elements is based specifically on the considerations of the desired properties, and could be very similar to those in existing conventional alloys for that purpose. Examples include refractory HEAs, light HEAs, HE bulk metallic glass (HEBMG), and high-entropy superalloys.

\subsection{Refractory HEAs}

First proposed by Senkov et al. in 2010, these are among the earliest examples of application-based redesigned materials [39]. These alloys are composed of refractory elements and are aimed for high temperature structural applications [40-47]. The primary phases in these alloys are generally BCC phase. Some alloys even have a single BCC structure. However, these multi-principal-element BCC phases are way stronger than pure BCC metals. For example, the hardness of the $\mathrm{Mo}_{20} \mathrm{Nb}_{20} \mathrm{Ta}_{20} \mathrm{~V}_{20} \mathrm{~W}_{20}$ alloy is $5250 \mathrm{MPa}$ [39]. More importantly, these alloys can be very resistant to thermal softening and can retain high hardness to temperatures as high as $1600{ }^{\circ} \mathrm{C}$ [42]. This is attributed to the sluggish diffusion effect in HEAs [42,48]. Therefore, these alloys have great potential in high temperature applications. Many other refractory HEAs were developed later to obtain improved strength, room temperature ductility, and density [40,41,47-54]. For example, $\mathrm{Al}$ addition in certain systems can bring advantages such as higher hardness and high-temperature strength, better room temperature plasticity, and lower density [48]. Additionally, NbMoTaW pillars show extraordinarily high yield strength of nearly $10 \mathrm{GPa}$. This is among the highest reported strength in micro-/nano-pillar compression. Furthermore, its fracture strain under compression is as high as 30\% [55]. 


\subsection{Light HEAs}

Because of the strong demand for energy conservation, the development of advanced light metals has been an important issue. However, conventional light metals often have mediocre strength and limited high temperature applications. In contrast, HEAs are known for high strength, good resistance to thermal softening, and good structural thermal stability [5]. Thus, light HEAs is a direction with great potential. Candidate elements include all low-density elements (e.g., $\mathrm{Al}, \mathrm{Mg}, \mathrm{Ti}, \mathrm{Si}, \mathrm{V}, \mathrm{Li}, \mathrm{Ca}, \mathrm{Sc}, \ldots$ ) and other elements to optimize properties. For example, Juan et al. designed $\mathrm{Al}_{20} \mathrm{Be}_{20} \mathrm{Fe}_{10} \mathrm{Si}_{15} \mathrm{Ti}_{35}$, which has a density of $3.91 \mathrm{~g} / \mathrm{cm}^{3}$ [56]. Li et al. developed the $\mathrm{Mg}_{x}(\mathrm{MnAlZnCu})_{100-x}$ alloys with densities ranging from 2.20 to $4.29 \mathrm{~g} / \mathrm{cm}^{3}$ and compressive strength around 400-500 MPa [57,58]. Stepanov et al. prepared the AlNbTiV alloy, which has a density of $5.59 \mathrm{~g} / \mathrm{cm}^{3}$, a high yield strength of $1029 \mathrm{MPa}$, and a ductility of $5 \%$ at room temperature [51]. Youssef et al. reported very high hardness (5.9 GPa) in $\mathrm{Al}_{20} \mathrm{Li}_{20} \mathrm{Mg}_{10} \mathrm{Sc}_{20} \mathrm{Ti}_{30}$, which also has very low density $\left(2.67 \mathrm{~g} / \mathrm{cm}^{3}\right)$ [59]. According to these studies, light HEAs do have high strength. As long as reasonable ductility can be achieved, these alloys will have great potential in the industry.

\subsection{High-Entropy Bulk Metallic Glass (HEBMG)}

Bulk metallic glasses (BMGs) have very high strength and good corrosion resistance. Thus, they have been extensively studied in the past few decades [60-64]. The composition of BMG is similar to HEAs in that both materials have multiple components. However, HEAs do not have a solvent element, and the configurational entropy is higher. It has been pointed out that higher configuration entropy could be beneficial for the glass forming ability (GFA) of BMGs $[65,66]$. Thus, it is reasonable to expect that some HEAs can be good glass formers. However, since most reported HEAs are crystalline, high configurational entropy apparently does not directly translate to glass formation. Other factors also play critical roles: Guo et al. showed that HEAs do form metallic glasses when they have large negative enthalpy of mixing and large atomic size difference [67]. These conditions are in line with the empirical rules for BMG formation [64]. The number of reported high entropy BMGs is still not large [67-75]. Some of the reported alloys do have larger critical diameters. For example, the diameters for $\mathrm{Pd}_{20} \mathrm{Pt}_{20} \mathrm{Cu}_{20} \mathrm{Ni}_{20} \mathrm{P}_{20}$ and $\mathrm{Ti}_{20} \mathrm{Zr}_{20} \mathrm{Hf}_{20} \mathrm{Be}_{20} \mathrm{Ni}_{20}$ glasses are 1 and $3 \mathrm{~mm}$, respectively [76,77]. The latter has a yield strength of $2142 \mathrm{MPa}$ and a plasticity of $4 \%$ [77]. HEBMGs can have other interesting properties. For example, $\mathrm{Zn}_{20} \mathrm{Ca}_{20} \mathrm{Sr}_{20} \mathrm{Yb}_{20}\left(\mathrm{Li}_{0.55} \mathrm{Mg}_{0.45}\right)_{20}$ shows homogeneous flow and a remarkable plasticity $(\sim 25 \%)$ at room temperature [68]. CaMgZnSrYb, a high-entropy modification of $\mathrm{Ca}_{65} \mathrm{Mg}_{15} \mathrm{Zn}_{20} \mathrm{BMG}$, was found to promote osteogenesis and bone formation after two weeks of implantation [69]. High entropy metallic glasses could also have improved thermal stability. Amorphous NbSiTaTiZr alloy film has an exceptionally high crystallization temperature of over $800^{\circ} \mathrm{C}$, which is probably the highest in any reported metallic glasses [78].

\subsection{High-Entropy Superalloys (HESA)}

High-entropy superalloys were proposed in 2015 [79]. Conventionally, the most important family of superalloys are the Ni-based ones. The replacement of $\mathrm{Ni}$ by other elements could reduce cost and/or density. The high structural stability and slow diffusion kinetics might be helpful for the thermal stability of the gamma prime phase. Yeh et al. developed a series of HESAs based on the Al-Co-Cr-Fe-Ni-Ti system [79-82]. These alloys do have reduced densities (below $8 \mathrm{~g} / \mathrm{cm}^{3}$ ) and lower raw material costs (about $20 \%$ lower than common Ni-based superalloys). Among these alloys, $\mathrm{Al}_{0.1} \mathrm{Co}_{1.5} \mathrm{CrFeNi}_{1.5} \mathrm{Ti}_{0.4}$ has good oxidation resistance, high hot hardness $\left(\sim 350 \mathrm{Hv}\right.$ at $\left.800{ }^{\circ} \mathrm{C}\right)$, and does not contain the detrimental $\eta$ phase [81]. $\mathrm{Ni}_{44} \mathrm{Al}_{3.9} \mathrm{Co}_{22.3} \mathrm{Cr}_{11.7} \mathrm{Fe}_{11.8} \mathrm{Ti}_{6.3}$ (in wt.\%) and $\mathrm{Ni}_{51} \mathrm{Al}_{5} \mathrm{Co}_{18} \mathrm{Cr}_{7} \mathrm{Fe}_{9} \mathrm{Ti}_{5} \mathrm{Ta}_{2} \mathrm{Mo}_{1.5} \mathrm{~W}_{1.5}$ (in wt.\%) show exceptional oxidation resistance and hot corrosion resistance that is superior to commercial superalloy CM247LC (Figure 1) [82]. Mazoni et al. optimized the Al-Co-Cr-Cu-Fe-Ni-Ti system [83-86] and obtained a promising alloy $\mathrm{Al}_{10} \mathrm{Co}_{25} \mathrm{Cr}_{8} \mathrm{Fe}_{15} \mathrm{Ni}_{36} \mathrm{Ti}_{6}$, which shows the $\gamma-\gamma^{\prime}$ microstructure characteristic of superalloys. This alloy has a tensile strength of 
$650 \mathrm{MPa}$ at $800^{\circ} \mathrm{C}$, which is higher than that of Inconel 617 (less than $500 \mathrm{MPa}$ ) [85]. Senkov et al. used a very different approach to obtain HESAs [54]. Using mostly refractory elements, they synthesized an alloy $\mathrm{AlMo}_{0.5} \mathrm{NbTa}_{0.5} \mathrm{TiZr}$ that contains high density cubic/plate-like precipitates embedded in a matrix - which looks similar to the structures of Ni-based superalloys. The precipitates have a disordered BCC structure, while the matrix has an ordered B2 structure. The strength of this alloy is significantly higher than Ni-based superalloys in the temperature range of $20^{\circ} \mathrm{C}$ to $1200^{\circ} \mathrm{C}$ [54].

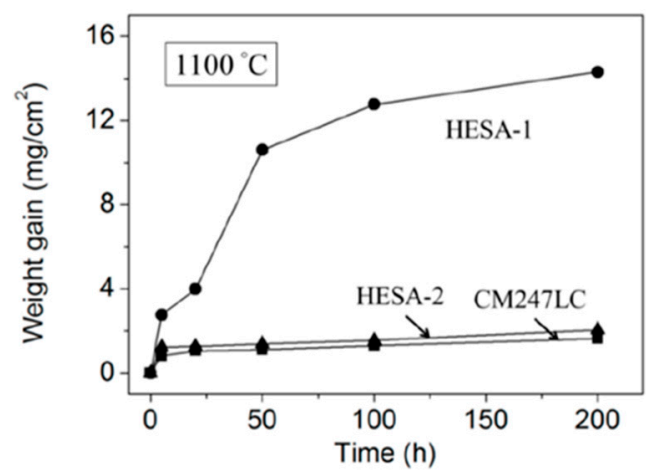

(a)

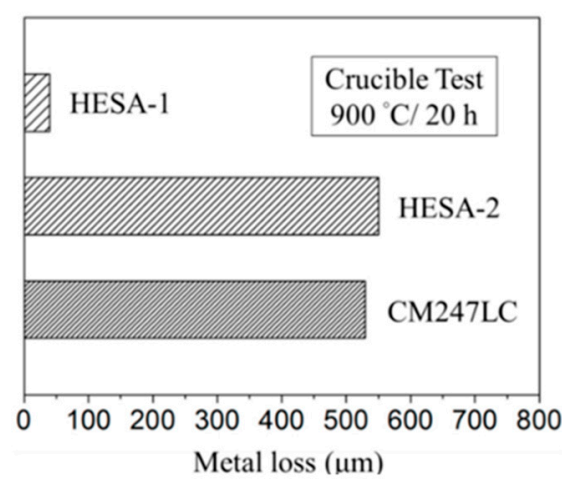

(b)

Figure 1. Comparison of the (a) isothermal oxidation resistance at $1100{ }^{\circ} \mathrm{C}$ and (b) hot corrosion resistance at $900{ }^{\circ} \mathrm{C}$ for $20 \mathrm{~h}$ of $\mathrm{Ni}_{44} \mathrm{Al}_{3.9} \mathrm{Co}_{22.3} \mathrm{Cr}_{11.7} \mathrm{Fe}_{11.8} \mathrm{Ti}_{6.3}$ (HESA-1, in wt.\%), $\mathrm{Ni}_{51} \mathrm{Al}_{5} \mathrm{Co}_{18} \mathrm{Cr}_{7} \mathrm{Fe}_{9} \mathrm{Ti}_{5} \mathrm{Ta}_{2} \mathrm{Mo}_{1.5} \mathrm{~W}_{1.5}$ (HESA-2, in wt.\%), and CM247LC [82].

Besides the above examples, there are many more other cases in this category. High-entropy hydrogen storage material is also an appealing direction. The CoFeMnTiVZr alloy can absorb/desorb hydrogen up to $1.6 \mathrm{wt} . \%$ at room temperature [87]. The ZrTiVCrFeNi alloy has a maximum hydrogen capacity of $1.8 \mathrm{wt} . \%$ when operated at $50{ }^{\circ} \mathrm{C}$ [88]. High-entropy magnetic materials also have interesting properties. For example, the $\mathrm{FeCoNiAl}_{0.2} \mathrm{Si}_{0.2}$ alloy has a good combination of properties including high saturation magnetization $(1.151 \mathrm{~T})$, high resistivity $(69.5 \mu \Omega-\mathrm{cm})$, and good malleability [89]. High-entropy diffusion barriers [78,90-92], high-entropy thermoelectric materials [93], high entropy protective coatings [94-98], etc., have also been reported. In fact, because materials for almost every application can be redesigned with the high-entropy concept, it is expected that there will be significantly more alloy systems in this category in the future.

\section{Enhancing the Entropy of Conventional Alloys}

The second strategy is to modify the composition of a known conventional alloy using the high-entropy concept. The modification can be made either to the solvent or to the solutes, and is illustrated in Figure 2a. The key point is to replace the existing solvent/solute with more elements. Modification of the solvent usually leads directly to a new HEA. In contrast, modification of the solute leads to a conventional alloy with enhanced entropy.

An early example of entropy enhancement of the solvent is in the field of BMG $[99,100]$. Based on the Zr-Al-Ni alloy, Cantor et al. performed what they called equiatomic substitution and developed the $\left(\mathrm{Ti}_{33} \mathrm{Zr}_{33} \mathrm{Hf}_{33}\right)_{100-x-y}\left(\mathrm{Ni}_{50} \mathrm{Cu}_{50}\right)_{x} \mathrm{Al}_{y}$ alloys [101]. The original solvent, $\mathrm{Zr}$, is replaced by $\mathrm{Ti}, \mathrm{Zr}$, $\mathrm{Hf}$ in equiatomic ratio. Among these alloys, $\left(\mathrm{Ti}_{33} \mathrm{Zr}_{33} \mathrm{Hf}_{33}\right)_{60}\left(\mathrm{Ni}_{50} \mathrm{Cu}_{50}\right)_{20} \mathrm{Al}_{20}$ showed very good GFA, with a wide supercooled liquid region of $124 \mathrm{~K}$ [102]. Another example is high-entropy bronzes/brasses [103]. These novel materials are developed by noting that $\mathrm{Cu}-\mathrm{Mn}-\mathrm{Ni}$ are mutually soluble. Therefore, the authors replaced the $\mathrm{Cu}$ element in conventional bronzes and brasses with equiatomic Cu-Mn-Ni ternary alloy, leading to compositions like $(\mathrm{CuMnNi})_{95} \mathrm{Sn}_{5}$ or $(\mathrm{CuMnNi})_{80} \mathrm{Zn}_{20}$. The strength, hardness, and plasticity of these alloys are considerably higher than standard commercial bronzes and brasses [103]. 


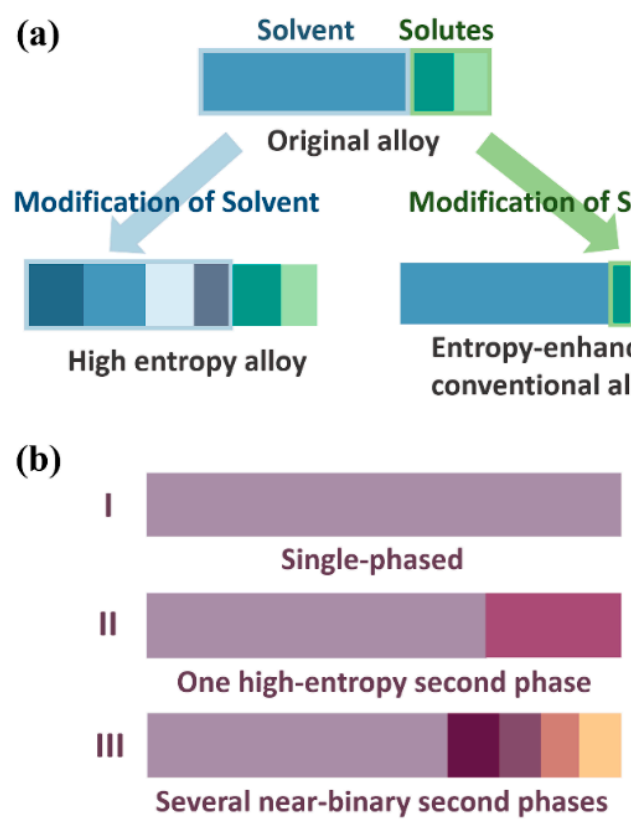

Figure 2. (a) Two approaches to enhance the entropy of conventional alloys. Modification of solvent typically leads to a new HEA, while modification of solute leads to an entropy-enhanced conventional alloy. Each color represents one element and the width of the colored region represents its concentration; (b) Three possible ideal cases of phase content in the alloy after solute modification. (I) single-phased; (II) one high-entropy second phase; (III) several near-binary second phases. Each color represents one phase in the alloy and the width of the phase region represents its volume fraction.

Entropy enhancement of the solute has been conducted to develop various high-entropy steels and high-entropy cast iron. Raabe et al. designed high entropy steels based on the Fe-Mn-Al-Si-C system [104]. They introduced more solutes to the Fe-Mn-C system and used the increased configurational entropy to stabilize a single-phase homogeneous FCC phase. Their results are quite pleasing-ultimate tensile strengths of up to $1000 \mathrm{MPa}$ and tensile elongations reaching up to $100 \%$ were reported [104]. Compared to conventional steels, these high-entropy steels possess a remarkable combination of properties, which is shown in Figure 3.

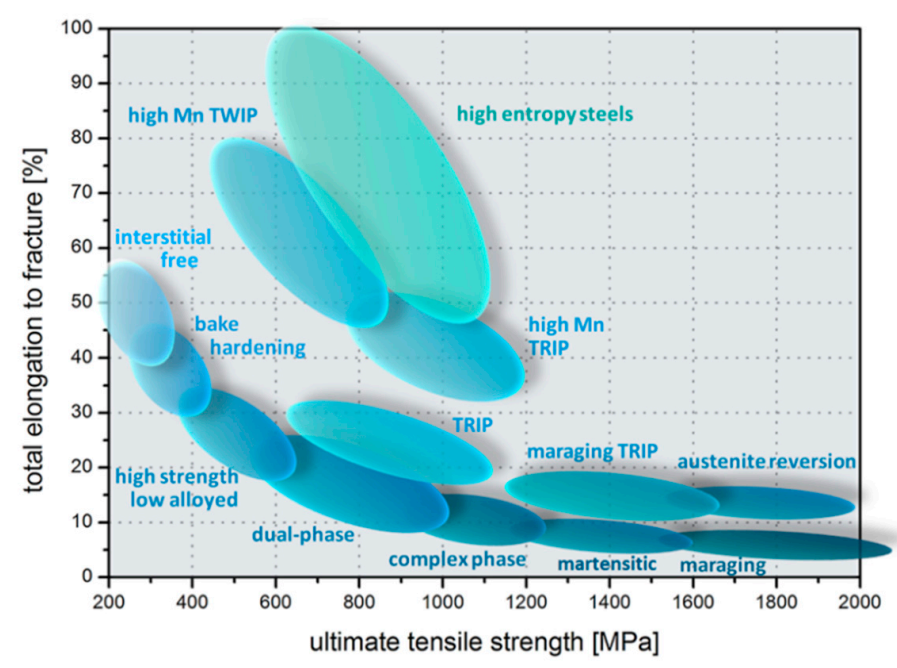

Figure 3. Overview diagram showing typical ranges of total elongation to fracture and ultimate tensile strength for a number of different classes of steels. Mechanical properties of reported high-entropy steels exceed that of many known steels [104]. 
A very different yet also interesting type of high-entropy steel is introduced by Pushin et al. [105]. They alloyed many strong carbide-forming elements $(\mathrm{Cr}, \mathrm{Mo}, \mathrm{W}$, and $\mathrm{V})$ to the $\mathrm{Fe}-\mathrm{C}$ system at the same time. The result is an ultra-fine-dispersed composite martensite-multicarbide structure with a very high hardness of HRC 62. It was noted that both binary and multi-component carbides were observed. A similar modification was made by Wang et al. to white cast iron Fe-20Cr-5C in 2011 [106]. They alloyed several carbide-forming elements such as Ti, V, Mo, and $\mathrm{W}$ simultaneously. The alloying led to two effects. Firstly, it suppressed the formation of primary coarse carbides and instead promoted the formation of various new carbide types $\left(\mathrm{M}_{7} \mathrm{C}_{3}, \mathrm{MC}\right.$, and $\left.\mathrm{M}_{6} \mathrm{C}\right)$. Secondly, it significantly refined the microstructure of the alloy owing to the competition between the carbide-forming elements. Therefore, the wear resistances of the high-entropy cast irons were markedly improved. For example, the volume loss rate of the 54Fe15.46Cr16.76C-3.45TiVMoW high-entropy cast iron is only one thirds of the original white cast iron. Based on the above examples, one can see that the entropy-enhanced alloys do show improved properties over the original ones. It is also noted that the composition, phase, and microstructure of the modified alloys can be very different. Depending on the modification made, the modified alloy could be an HEA or a conventional alloy, single-phased or multi-phased. In the case of a multi-phased alloy, the second phase(s) could be one high-entropy phase, various individual near-binary phases, or a mixture of the two extremes. These possibilities are partially illustrated with Figure $2 \mathrm{~b}$. The wide diversity in the structure and phase of the modified alloys allows considerable freedom for the adjustment of properties, making this strategy useful for the improvement of conventional alloy systems.

\section{Incorporating Second Phases}

HEAs are known to form simple phases (i.e., FCC, BCC, and HCP structures, including both ordered and disordered versions) easily, and these simple phases can have many unique properties [55,107-110]. However, the strengths of simple-phased HEAs are usually limited. In particular, alloys that have FCC structures are quite soft. Among common strengthening mechanisms, second-phase strengthening is known to be the most effective $[3,111]$. Second phases can be incorporated directly in the cast state, or be precipitated in a matrix after heat treatment. HEAs have slow diffusion kinetics [6] and can form nanoscale second phase/precipitates in the as-cast state $[9,10,23,112]$, after prolonged annealing at $700^{\circ} \mathrm{C}[113]$, and even after homogenization at $1100{ }^{\circ} \mathrm{C}$ and subsequently furnace cooled [11]. Therefore, HEAs are very suitable for this strengthening mechanism. Indeed, it has been reported that second phases can markedly enhance the mechanical properties of HEAs. For example, the precipitation of hard $\eta-\mathrm{Ni}_{3} \mathrm{Ti}$ phase drastically improve the wear resistance of the $\mathrm{Co}_{27.3} \mathrm{Cr}_{18.2} \mathrm{Fe}_{18.2} \mathrm{Ni}_{27.3} \mathrm{Ti}_{9.1}$ alloy [114]. Another example is in the $\mathrm{AlCoCr}_{x} \mathrm{FeMo}_{0.5} \mathrm{Ni}$ alloy, where the formation of $\sigma$ phase leads to a better resistance to thermal softening at elevated temperatures [115]. These results reveal that second-phase strengthening works well in HEAs.

In view of this, very recently many groups aim to design HEAs with intentionally introduced second phase with tailored morphology. For example, He et al. alloyed a small amount of Ti and $\mathrm{Al}$ into $\mathrm{FeCoNiCr}$ to precipitate nanosized coherent reinforcing phase, $\mathrm{L}_{2}-\mathrm{Ni}_{3}(\mathrm{Ti}, \mathrm{Al})$, in an $\mathrm{FCC}$ FeCoNiCr matrix [116]. This $\gamma-\gamma^{\prime}$ structure is similar to that in Ni-based superalloys and leads to significant precipitation hardening effect. Thermomechanically processed $(\mathrm{FeCoNiCr})_{94} \mathrm{Ti}_{2} \mathrm{Al}_{4}$ alloy can reach yield strength of over $1 \mathrm{GPa}$ while still remain of good elongation of $17 \%$. Such combination of properties outperforms most advanced steels, as is shown in Figure 4 [116]. Guo et al., on the other hand, alloyed $\mathrm{C}$ into the $\mathrm{Mo}_{0.5} \mathrm{NbHf}_{0.5} \mathrm{ZrTi}$ refractory HEA [117]. The alloying leads to the formation of $\mathrm{MC}\left(\mathrm{M}\right.$ is $\mathrm{Hf}, \mathrm{Nb}, \mathrm{Zr}$, and Ti) carbide particulates. The $\mathrm{Mo}_{0.5} \mathrm{NbHf}_{0.5} \mathrm{ZrTiC}_{0.1}$ alloy shows a compressive strength of $2139 \mathrm{MPa}$ and a fracture strain of $38.4 \%$. Compared with the corresponding values of the original alloy (1538 MPa and $24.6 \%$ ), addition of $C$ improves both the strength and plasticity of the alloy. Another example is AlCoCrFeNi 2.1 , an alloy which comprises two phases: FCC and B2. In its cast state, the two phases form a lamellar structure and the alloy is soft. It can be thermomechanically 
processed to achieve an ultrafine grained duplex microstructure which has well-balanced mechanical properties-a yield strength of $1100 \mathrm{MPa}$ and an elongation of $12 \%$ [118].

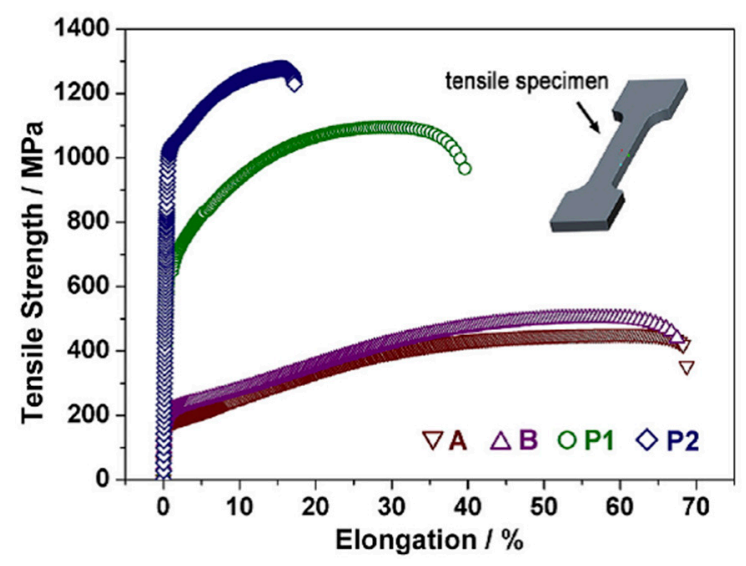

Figure 4. Tensile properties of four HEAs at room temperature [116]. A: FeCoNiCr, as-homogenized; B: $(\mathrm{FeCoNiCr})_{94} \mathrm{Ti}_{2} \mathrm{Al}_{4}$, as-homogenized; $\left.\mathrm{P} 1: \mathrm{FeCoNiCr}\right)_{94} \mathrm{Ti}_{2} \mathrm{Al}_{4}$, thermomechanically processed; and P2: $\mathrm{FeCoNiCr})_{94} \mathrm{Ti}_{2} \mathrm{Al}_{4}$, thermomechanically processed. The thermomechanical processing of $\mathrm{P} 1$ and P2 are different, see the original work for details.

Based on the above, the introduction of appropriate second phases with tailored morphology is a very effective strategy for property enhancement. However, the key difficulty in this regard lies in the complexity of composition design. This will be discussed further in the final part of this paper.

\section{Notes on the Classification of the Alloys}

Some notes on the classification of the alloy are presented here. Firstly, this paper discusses the design strategy of advanced HEAs. Therefore, the classification of alloys is based on the design concept described in the original publication, not on the phase/structure of the resulted alloy. For example, carbide strengthened high-entropy steel is classified in the second category instead of the third because the design concept of the author is based on enhancing the entropy of an existing steel.

Secondly, the three strategies are not mutually exclusive; one can adopt one or more strategies simultaneously to design an alloy. For example, HE superalloys are designed to replace current Ni-based superalloys; which means they are designed specifically for high temperature structural applications [80]. For that purpose, the gamma/gamma prime microstructure in Ni-based superalloys is known to be very helpful. Thus, the authors also want to mimic that microstructure. Therefore, both the first and the third strategies are used in this case.

Thirdly, when more than one strategy is used to design an alloy, the alloy should be classified under the category with higher hierarchy whenever possible. For example, in the case of HE superalloys, the incorporation of the gamma prime phase is because it benefits the high temperature strength. In other words, the third strategy is adopted because of the need in the first strategy. Therefore, HE superalloys are classified under the first category.

\section{Outlook and Concluding Remarks}

Some important issues in the future development of advanced HEAs are discussed below. Firstly, the composition design of HEAs is still challenging and sometimes intimidating. This is particularly true when intermetallic phases are involved. Our current knowledge about the design principles of HEAs is largely focused on designing simple-structured HEAs (i.e., FCC, BCC, HCP, and their derivative structures) $[5,110]$. However, because many advanced HEAs contain multiple phases including intermetallics, knowledge about controlling the type and amount of intermetallic phases becomes crucial. In this regard, the following directions are worth studying: 
(1) High-entropy intermetallics. Although in many cases the intermetallics in HEAs are just conventional binary/ternary intermetallics, sometimes the so-called high-entropy intermetallics (HEI) can appear. HEIs have crystal structures similar to binary intermetallic phases but they are composed of multiple principal elements. For example, the composition of the Laves phase in $\mathrm{CoCrFeNiHf}$ is (in at. $\%$ ): $15.1 \% \mathrm{Cr}, 19.4 \% \mathrm{Fe}, 21.4 \% \mathrm{Co}, 20.1 \% \mathrm{Ni}$, and $24.0 \% \mathrm{Hf}[119,120]$. This composition is not far from a quinary equimolar alloy, which is apparently different from conventional binary/ternary Laves phases. High-entropy intermetallics represent a new class of material. Their behavior and properties could be different from their conventional counterparts and deserve more attention.

(2) CALPHAD technique. The compositional space in HEAs is simply too enormous to explore by experiments alone. This makes computational skills, in particular CALPHAD, extremely important. It was suggested [3] and later on verified that CALPHAD can quickly screen out alloys that are apparently unsuitable, thus the speed of development can be increased by several orders of magnitude [121-123]. A major issue is that the thermodynamic database for HEAs is far from complete. This means that depending on alloy composition, the accuracy of CALPHAD predictions can vary significantly. Therefore, the development of more multi-component databases is urgently needed.

(3) Practical design rules concerning intermetallic phases in HEAs. Although the CALPHAD approach has unparalleled advantage in term of speed, the software and databases are costly and accuracy is still a major issue (as mentioned above). Therefore, practical alloy design principles based on experimental results is still necessary. Unfortunately, our knowledge about the stability and selection of intermetallic phases in HEAs is very rare. Preliminary results includes a general criterion on the selection of intermetallic phase [120], and criteria specific to certain phases types such as sigma phase [124,125] and Laves phase [126]. Clearly, more work is required in this respect.

Secondly, because many advanced HEAs are aimed for real applications, cost becomes a key issue. This is a major drawback of HEAs. The introduction of multiple principal elements makes it difficult to use only cheap elements. Therefore, the following directions are of interest:

(1) Focus on replacing expensive conventional alloys. A reasonable approach is to find applications where the current material is already expensive. Then, use the three strategies mentioned in this paper to find better solutions. Since the original material is expensive, the barrier of using HEAs is lowered as long as HEAs provide improved properties. Ni-based superalloys and $\mathrm{Zr}$ alloys are good examples of expensive conventional alloys.

(2) Avoid expensive elements. The use of cheap elements directly reduces the material cost. For example, $\mathrm{Co}$ is an expensive element but it is very commonly used in HEAs. Therefore, alloys with reduced or no Co have clear advantage. Indeed, some researchers have explored Co-free HEAs $[127,128]$. Most of these studies start from a known HEA with good properties and try to replace Co with other elements. The difficult part, of course, is to preserve the good properties of the original alloy. Co is not the only expensive element used in HEAs. It is expected that the replacement of expensive elements will become a common practice in alloy design.

(3) Explore medium-entropy alloys. Medium-entropy alloys (MEAs) have been highlighted as an important future direction because of their great potential $[129,130]$. But MEAs have another competitive edge. The reduced alloying content in MEAs can lower the material cost, particularly if the base element is also cheap. Fe-based MEAs are good examples. In this regard there is still a lot of space to explore.

In summary, the development of HEAs has entered a different stage in recent years. Unlike early studies that are largely of exploratory nature, HEAs studied nowadays are usually designed to meet clear goals, and have carefully chosen composing elements, deliberately introduced multiple phases, 
and tailored microstructures. These alloys are referred to here as advanced HEAs. The migration to advanced HEAs clearly signifies the progress of our knowledge on these novel materials. Based on a broad literature survey on advanced HEAs, the design strategies of these materials are classified into three categories, namely application-based redesigning, enhancing the entropy of conventional alloys, and incorporating second phases. Representative works in each category are discussed. It should be noted that the three strategies are not mutually exclusive. Finally, important issues in the development of advanced HEAs are pointed out. These include difficulties in alloy design and cost reduction. Future directions are also discussed accordingly.

Acknowledgments: Ming-Hung Tsai gratefully acknowledges valuable discussions with An-Chou Yeh, Weihua Wang and Jien-Wei Yeh. This work was supported by the Ministry of Science and Technology of Taiwan under grant MOST-104-2221-E-005-015.

Conflicts of Interest: The author declares no conflict of interest.

\section{References}

1. Yeh, J.W.; Chen, S.K.; Lin, S.J.; Gan, J.Y.; Chin, T.S.; Shun, T.T.; Tsau, C.H.; Chang, S.Y. Nanostructured high-entropy alloys with multiple principal elements: Novel alloy design concepts and outcomes. Adv. Eng. Mater. 2004, 6, 299-303. [CrossRef]

2. Yeh, J.W. Alloy Design Strategies and Future Trends in High-Entropy Alloys. JOM 2013, 65, $1759-1771$. [CrossRef]

3. Miracle, D.; Miller, J.; Senkov, O.; Woodward, C.; Uchic, M.; Tiley, J. Exploration and Development of High Entropy Alloys for Structural Applications. Entropy 2014, 16, 494-525. [CrossRef]

4. Yeh, J.W. Recent progress in high-entropy alloys. Ann. Chim. Sci. Mater. 2006, 31, 633-648. [CrossRef]

5. Tsai, M.H.; Yeh, J.W. High-Entropy Alloys: A Critical Review. Mater. Res. Lett. 2014, 2, 107-123. [CrossRef]

6. Tsai, K.Y.; Tsai, M.H.; Yeh, J.W. Sluggish diffusion in Co-Cr-Fe-Mn-Ni high-entropy alloys. Acta Mater. 2013, 61, 4887-4897. [CrossRef]

7. Mukhopadhyay, N.K. High entropy alloys: A renaissance in physical metallurgy. Curr. Sci. 2015, 109, 665-667.

8. Tong, C.J.; Chen, M.R.; Chen, S.K.; Yeh, J.W.; Shun, T.T.; Lin, S.J.; Chang, S.Y. Mechanical performance of the $\mathrm{Al}_{x} \mathrm{CoCrCuFeNi}$ high-entropy alloy system with multiprincipal elements. Metall. Mater. Trans. A 2005, 36, 1263-1271. [CrossRef]

9. Tong, C.J.; Chen, Y.L.; Chen, S.K.; Yeh, J.W.; Shun, T.T.; Tsau, C.H.; Lin, S.J.; Chang, S.Y. Microstructure characterization of $\mathrm{Al}_{x} \mathrm{CoCrCuFeNi}$ high-entropy alloy system with multiprincipal elements. Metall. Mater. Trans. A 2005, 36, 881-893. [CrossRef]

10. Singh, S.; Wanderka, N.; Murty, B.S.; Glatzel, U.; Banhart, J. Decomposition in multi-component AlCoCrCuFeNi high-entropy alloy. Acta Mater. 2011, 59, 182-190. [CrossRef]

11. Tsai, M.H.; Yuan, H.; Cheng, G.; Xu, W.; Tsai, K.Y.; Tsai, C.W.; Jian, W.W.; Juan, C.C.; Shen, W.J.; Chuang, M.H.; et al. Morphology, structure and composition of precipitates in $\mathrm{Al}_{0.3} \mathrm{CoCrCu}_{0.5} \mathrm{FeNi}$ high-entropy alloy. Intermetallics 2013, 32, 329-336. [CrossRef]

12. Tung, C.C.; Yeh, J.W.; Shun, T.T.; Chen, S.K.; Huang, Y.S.; Chen, H.C. On the elemental effect of AlCoCrCuFeNi high-entropy alloy system. Mater. Lett. 2007, 61, 1-5. [CrossRef]

13. Wen, L.H.; Kou, H.C.; Li, J.S.; Chang, H.; Xue, X.Y.; Zhou, L. Effect of aging temperature on microstructure and properties of AlCoCrCuFeNi high-entropy alloy. Intermetallics 2009, 17, 266-269. [CrossRef]

14. Tsai, C.W.; Chen, Y.L.; Tsai, M.H.; Yeh, J.W.; Shun, T.T.; Chen, S.K. Deformation and annealing behaviors of high-entropy alloy $\mathrm{Al}_{0.5} \mathrm{CoCrCuFeNi.} \mathrm{J.} \mathrm{Alloys} \mathrm{Compd.} \mathrm{2009,} \mathrm{486,} \mathrm{427-435.} \mathrm{[CrossRef]}$

15. Zhang, K.B.; Fu, Z.Y.; Zhang, J.Y.; Shi, J.; Wang, W.M.; Wang, H.; Wang, Y.C.; Zhang, Q.J. Annealing on the structure and properties evolution of the $\mathrm{CoCrFeNiCuAl}$ high-entropy alloy. J. Alloys Compd. 2010, 502, 295-299. [CrossRef]

16. Tsai, C.W.; Tsai, M.H.; Yeh, J.W.; Yang, C.C. Effect of temperature on mechanical properties of $\mathrm{Al}_{0.5} \mathrm{CoCrCuFeNi}$ wrought alloy. J. Alloys Compd. 2010, 490, 160-165. [CrossRef]

17. Wang, F.J.; Zhang, Y.; Chen, G.L.; Davies, H.A. Tensile and compressive mechanical behavior of a $\mathrm{CoCrCuFeNiAl}_{0.5}$ high entropy alloy. Int. J. Mod. Phys. B 2009, 23, 1254-1259. [CrossRef] 
18. Kuznetsov, A.V.; Shaysultanov, D.G.; Stepanov, N.D.; Salishchev, G.A.; Senkov, O.N. Tensile properties of an AlCrCuNiFeCo high-entropy alloy in as-cast and wrought conditions. Mater. Sci. Eng. A 2012, 533, 107-118. [CrossRef]

19. Kuznetsov, A.V.; Shaysultanov, D.G.; Stepanov, N.D.; Salishchev, G.A.; Senkov, O.N. Superplasticity of AlCoCrCuFeNi High Entropy Alloy. Mater. Sci. Forum 2013, 735, 146-151. [CrossRef]

20. Wu, J.M.; Lin, S.J.; Yeh, J.W.; Chen, S.K.; Huang, Y.S. Adhesive wear behavior of $\mathrm{Al}_{\mathrm{x}} \mathrm{CoCrCuFeNi}$ high-entropy alloys as a function of aluminum content. Wear 2006, 261, 513-519. [CrossRef]

21. Hemphill, M.A.; Yuan, T.; Wang, G.Y.; Yeh, J.W.; Tsai, C.W.; Chuang, A.; Liaw, P.K. Fatigue behavior of $\mathrm{Al}_{0.5} \mathrm{CoCrCuFeNi}$ high entropy alloys. Acta Mater. 2012, 60, 5723-5734. [CrossRef]

22. Liu, Z.Y.; Guo, S.; Liu, X.J.; Ye, J.C.; Yang, Y.; Wang, X.L.; Yang, L.; An, K.; Liu, C.T. Micromechanical characterization of casting-induced inhomogeneity in an $\mathrm{Al}_{0.8} \mathrm{CoCrCuFeNi}$ high-entropy alloy. Scr. Mater. 2011, 64, 868-871. [CrossRef]

23. Shun, T.T.; Du, Y.C. Microstructure and tensile behaviors of FCC $\mathrm{Al}_{0.3} \mathrm{CoCrFeNi}$ high entropy alloy. J. Alloys Compd. 2009, 479, 157-160. [CrossRef]

24. Wang, W.R.; Wang, W.L.; Wang, S.C.; Tsai, Y.C.; Lai, C.H.; Yeh, J.W. Effects of Al addition on the microstructure and mechanical property of $\mathrm{Al}_{x} \mathrm{CoCrFeNi}$ high-entropy alloys. Intermetallics 2012, 26, 44-51. [CrossRef]

25. Kao, Y.F.; Chen, T.J.; Chen, S.K.; Yeh, J.W. Microstructure and mechanical property of as-cast, -homogenized, and -deformed $\mathrm{Al}_{x} \mathrm{CoCrFeNi}(0 \leqslant x \leqslant 2)$ high-entropy alloys. J. Alloys Compd. 2009, 488, 57-64. [CrossRef]

26. Li, C.; Li, J.C.; Zhao, M.; Jiang, Q. Effect of aluminum contents on microstructure and properties of $\mathrm{Al}_{x} \mathrm{CoCrFeNi}$ alloys. J. Alloys Compd. 2010, 504, S515-S518. [CrossRef]

27. Lin, C.M.; Tsai, H.L. Evolution of microstructure, hardness, and corrosion properties of high-entropy $\mathrm{Al}_{0.5} \mathrm{CoCrFeNi}$ alloy. Intermetallics 2011, 19, 288-294. [CrossRef]

28. Wang, Y.P.; Li, B.S.; Ren, M.X.; Yang, C.; Fu, H.Z. Microstructure and compressive properties of $\mathrm{AlCrFeCoNi}$ high entropy alloy. Mater. Sci. Eng. A 2008, 491, 154-158. [CrossRef]

29. Zhuang, Y.X.; Liu, W.J.; Chen, Z.Y.; Xue, H.D.; He, J.C. Effect of elemental interaction on microstructure and mechanical properties of FeCoNiCuAl alloys. Mater. Sci. Eng. A 2012, 556, 395-399. [CrossRef]

30. Ma, S.G.; Zhang, Y. Effect of $\mathrm{Nb}$ addition on the microstructure and properties of AlCoCrFeNi high-entropy alloy. Mater. Sci. Eng. A 2012, 532, 480-486. [CrossRef]

31. Li, B.S.; Wang, Y.R.; Ren, M.X.; Yang, C.; Fu, H.Z. Effects of Mn, Ti and V on the microstructure and properties of AlCrFeCoNiCu high entropy alloy. Mater. Sci. Eng. A 2008, 498, 482-486. [CrossRef]

32. Chen, M.R.; Lin, S.J.; Yeh, J.W.; Chen, S.K.; Huang, Y.S.; Chuang, M.H. Effect of vanadium addition on the microstructure, hardness, and wear resistance of $\mathrm{Al}_{0.5} \mathrm{CoCrCuFeNi}$ high-entropy alloy. Metall. Mater. Trans. A 2006, 37, 1363-1369. [CrossRef]

33. Hu, Z.H.; Zhan, Y.Z.; Zhang, G.H.; She, J.; Li, C.H. Effect of rare earth Y addition on the microstructure and mechanical properties of high entropy AlCoCrCuNiTi alloys. Mater. Des. 2010, 31, 1599-1602. [CrossRef]

34. Liu, L.; Zhu, J.B.; Li, L.; Li, J.C.; Jiang, Q. Microstructure and tensile properties of FeMnNiCuCoSn high entropy alloys. Mater. Des. 2013, 44, 223-227. [CrossRef]

35. Liu, L.; Zhu, J.B.; Zhang, C.; Li, J.C.; Jiang, Q. Microstructure and the properties of FeCoCuNiSn high entropy alloys. Mater. Sci. Eng. A 2012, 548, 64-68. [CrossRef]

36. Pradeep, K.G.; Wanderka, N.; Choi, P.; Banhart, J.; Murty, B.S.; Raabe, D. Atomic-scale compositional characterization of a nanocrystalline $\mathrm{AlCrCuFeNiZn} \mathrm{high-entropy} \mathrm{alloy} \mathrm{using} \mathrm{atom} \mathrm{probe} \mathrm{tomography.}$ Acta Mater. 2013, 61, 4696-4706. [CrossRef]

37. Shun, T.T.; Du, Y.C. Age hardening of the $\mathrm{Al}_{0.3} \mathrm{CoCrFeNiC}_{0.1}$ high entropy alloy. J. Alloys Compd. 2009, 478, 269-272. [CrossRef]

38. Zhu, J.M.; Fu, H.M.; Zhang, H.F.; Wang, A.M.; Li, H.; Hu, Z.Q. Microstructure and compressive properties of multiprincipal component $\mathrm{AlCoCrFeNiC}_{x}$ alloys. J. Alloys Compd. 2011, 509, 3476-3480. [CrossRef]

39. Senkov, O.N.; Wilks, G.B.; Miracle, D.B.; Chuang, C.P.; Liaw, P.K. Refractory high-entropy alloys. Intermetallics 2010, 18, 1758-1765. [CrossRef]

40. Senkov, O.N.; Scott, J.M.; Senkova, S.V.; Miracle, D.B.; Woodward, C.F. Microstructure and room temperature properties of a high-entropy TaNbHfZrTi alloy. J. Alloys Compd. 2011, 509, 6043-6048. [CrossRef]

41. Senkov, O.N.; Senkova, S.V.; Woodward, C.; Miracle, D.B. Low-density, refractory multi-principal element alloys of the Cr-Nb-Ti-V-Zr system: Microstructure and phase analysis. Acta Mater. 2013, 61, 1545-1557. [CrossRef] 
42. Senkov, O.N.; Wilks, G.B.; Scott, J.M.; Miracle, D.B. Mechanical properties of $\mathrm{Nb}_{25} \mathrm{Mo}_{25} \mathrm{Ta}_{25} \mathrm{~W}_{25}$ and $\mathrm{V}_{20} \mathrm{Nb}_{20} \mathrm{Mo}_{20} \mathrm{Ta}_{20} \mathrm{~W}_{20}$ refractory high entropy alloys. Intermetallics 2011, 19, 698-706. [CrossRef]

43. Senkov, O.N.; Woodward, C.F. Microstructure and properties of a refractory $\mathrm{NbCrMo}_{0.5} \mathrm{Ta}_{0.5} \mathrm{TiZr}_{\mathrm{Zlloy}}$ Mater. Sci. Eng. A 2011, 529, 311-320. [CrossRef]

44. Senkov, O.N.; Scott, J.M.; Senkova, S.V.; Meisenkothen, F.; Miracle, D.B.; Woodward, C.F. Microstructure and elevated temperature properties of a refractory TaNbHfZrTi alloy. J. Mater. Sci. 2012, 47, 4062-4074. [CrossRef]

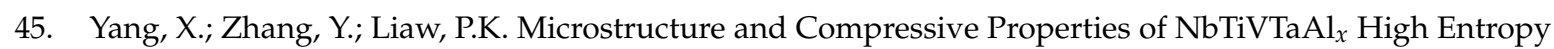
Alloys. Procedia Eng. 2012, 36, 292-298. [CrossRef]

46. Senkov, O.N.; Senkova, S.V.; Miracle, D.B.; Woodward, C. Mechanical properties of low-density, refractory multi-principal element alloys of the Cr-Nb-Ti-V-Zr system. Mater. Sci. Eng. A 2013, 565, 51-62. [CrossRef]

47. Juan, C.C.; Tsai, M.H.; Tsai, C.W.; Lin, C.M.; Wang, W.R.; Yang, C.C.; Chen, S.K.; Lin, S.J.; Yeh, J.W. Enhanced mechanical properties of HfMoTaTiZr and HfMoNbTaTiZr refractory high-entropy alloys. Intermetallics 2015, 62, 76-83. [CrossRef]

48. Senkov, O.N.; Senkova, S.V.; Woodward, C. Effect of aluminum on the microstructure and properties of two refractory high-entropy alloys. Acta Mater. 2014, 68, 214-228. [CrossRef]

49. Guo, N.N.; Wang, L.; Luo, L.S.; Li, X.Z.; Su, Y.Q.; Guo, J.J.; Fu, H.Z. Microstructure and mechanical properties of refractory MoNbHfZrTi high-entropy alloy. Mater. Des. 2015, 81, 87-94. [CrossRef]

50. Lin, C.M.; Juan, C.C.; Chang, C.H.; Tsai, C.W.; Yeh, J.W. Effect of Al addition on mechanical properties and microstructure of refractory $\mathrm{Al}_{x} \mathrm{HfNbTaTiZr}$ alloys. J. Alloys Compd. 2015, 624, 100-107. [CrossRef]

51. Stepanov, N.D.; Shaysultanov, D.G.; Salishchev, G.A.; Tikhonovsky, M.A. Structure and mechanical properties of a light-weight AlNbTiV high entropy alloy. Mater. Lett. 2015, 142, 153-155. [CrossRef]

52. Stepanov, N.D.; Yurchenko, N.Y.; Sokolovsky, V.S.; Tikhonovsky, M.A.; Salishchev, G.A. An AlNbTiVZr 0.5 high-entropy alloy combining high specific strength and good ductility. Mater. Lett. 2015, 161, 136-139. [CrossRef]

53. Juan, C.C.; Tseng, K.K.; Hsu, W.L.; Tsai, M.H.; Tsai, C.W.; Lin, C.M.; Chen, S.K.; Lin, S.J.; Yeh, J.W. Solution strengthening of ductile refractory $\mathrm{HfMo}_{x} \mathrm{NbTaTiZr}$ high-entropy alloys. Mater. Lett. 2016, 175, $284-287$. [CrossRef]

54. Senkov, O.; Isheim, D.; Seidman, D.; Pilchak, A. Development of a refractory high entropy superalloy. Entropy 2016, 18, 102. [CrossRef]

55. Zou, Y.; Ma, H.; Spolenak, R. Ultrastrong ductile and stable high-entropy alloys at small scales. Nat. Commun. 2015, 6, 7748. [CrossRef] [PubMed]

56. Juan, C.C.; Yeh, J.W.; Chin, T.S. A novel light high-entropy alloy $\mathrm{Al}_{20} \mathrm{Be}_{20} \mathrm{Fe}_{10} \mathrm{Si}_{15} \mathrm{Ti}_{35}$. In Proceedings of the E-MRS Fall Meeting, Warsaw, Poland, 14-18 September 2009.

57. Li, R.; Gao, J.C.; Fan, K. Study to microstructure and mechanical properties of Mg containing high entropy alloys. Mater. Sci. Forum 2010, 650, 265-271. [CrossRef]

58. Li, R.; Gao, J.C.; Fan, K. Microstructure and mechanical properties of MgMnAlZnCu high entropy alloy cooling in three conditions. Mater. Sci. Forum 2011, 686, 235-241. [CrossRef]

59. Youssef, K.M.; Zaddach, A.J.; Niu, C.; Irving, D.L.; Koch, C.C. A novel low-density, high-hardness, high-entropy alloy with close-packed single-phase nanocrystalline structures. Mater. Res. Lett. 2015, 3, 95-99. [CrossRef]

60. Johnson, W.L. Bulk glass-forming metallic alloys: Science and technology. MRS Bull. 1999, 24, 42-56. [CrossRef]

61. Wang, W.H.; Dong, C.; Shek, C.H. Bulk metallic glasses. Mater. Sci. Eng. R Rep. 2004, 44, 45-89. [CrossRef]

62. Loffler, J.F. Bulk metallic glasses. Intermetallics 2003, 11, 529-540. [CrossRef]

63. Inoue, A.; Takeuchi, A. Recent development and application products of bulk glassy alloys. Acta Mater. 2011, 59, 2243-2267. [CrossRef]

64. Inoue, A. Stabilization of metallic supercooled liquid and bulk amorphous alloys. Acta Mater. 2000, 48, 279-306. [CrossRef]

65. Guo, S.; Liu, C.T. Phase stability in high entropy alloys: Formation of solid-solution phase or amorphous phase. Prog. Nat. Sci. Mater. Int. 2011, 21, 433-446. [CrossRef]

66. Xia, M.X.; Zhang, S.G.; Ma, C.L.; Li, J.G. Evaluation of glass-forming ability for metallic glasses based on order-disorder competition. Appl. Phys. Lett. 2006, 89, 091917. [CrossRef] 
67. Guo, S.; Hu, Q.; Ng, C.; Liu, C.T. More than entropy in high-entropy alloys: Forming solid solutions or amorphous phase. Intermetallics 2013, 41, 96-103. [CrossRef]

68. Zhao, K.; Xia, X.X.; Bai, H.Y.; Zhao, D.Q.; Wang, W.H. Room temperature homogeneous flow in a bulk metallic glass with low glass transition temperature. Appl. Phys. Lett. 2011, 98, 141913. [CrossRef]

69. Li, H.F.; Xie, X.H.; Zhao, K.; Wang, Y.B.; Zheng, Y.F.; Wang, W.H.; Qin, L. In vitro and in vivo studies on biodegradable CaMgZnSrYb high-entropy bulk metallic glass. Acta Biomater. 2013, 9, 8561-8573. [CrossRef] [PubMed]

70. Chen, Y.Y.; Hong, U.T.; Yeh, J.W.; Shih, H.C. Mechanical properties of a bulk $\mathrm{Cu}_{0.5} \mathrm{NiAlCoCrFeSi} \mathrm{glassy} \mathrm{alloy}$ in 288 degrees $C$ high-purity water. Appl. Phys. Lett. 2005, 87. [CrossRef]

71. Gao, X.Q.; Zhao, K.; Ke, H.B.; Ding, D.W.; Wang, W.H.; Bai, H.Y. High mixing entropy bulk metallic glasses. J. Non-Cryst. Solids 2011, 357, 3557-3560. [CrossRef]

72. Cunliffe, A.; Plummer, J.; Figueroa, I.; Todd, I. Glass formation in a high entropy alloy system by design. Intermetallics 2012, 23, 204-207. [CrossRef]

73. Ding, H.Y.; Yao, K.F. High entropy $\mathrm{Ti}_{20} \mathrm{Zr}_{20} \mathrm{Cu}_{20} \mathrm{Ni}_{20} \mathrm{Be}_{20}$ bulk metallic glass. J. Non-Cryst. Solids 2013, 364, 9-12. [CrossRef]

74. Wang, J.; Zheng, Z.; Xu, J.; Wang, Y. Microstructure and magnetic properties of mechanically alloyed FeSiSAlNi (Nb) high entropy alloys. J. Magn. Magn. Mater. 2014, 355, 58-64. [CrossRef]

75. Wang, W.H. High-entropy metallic glasses. JOM 2014, 66, 2067-2077. [CrossRef]

76. Takeuchi, A.; Chen, N.; Wada, T.; Yokoyama, Y.; Kato, H.; Inoue, A.; Yeh, J.W. $\mathrm{Pd}_{20} \mathrm{Pt}_{20} \mathrm{Cu}_{20} \mathrm{Ni}_{20} \mathrm{P}_{20}$ high-entropy alloy as a bulk metallic glass in the centimeter. Intermetallics 2011, 19, 1546-1554. [CrossRef]

77. Zhao, S.F.; Shao, Y.; Liu, X.; Chen, N.; Ding, H.Y.; Yao, K.F. Pseudo-quinary $\mathrm{Ti}_{20} \mathrm{Zr}_{20} \mathrm{Hf}_{20} \mathrm{Be}_{20}\left(\mathrm{Cu}_{20-x} \mathrm{Ni}_{x}\right)$ high entropy bulk metallic glasses with large glass forming ability. Mater. Des. 2015, 87, 625-631. [CrossRef]

78. Tsai, M.H.; Wang, C.W.; Tsai, C.W.; Shen, W.J.; Yeh, J.W.; Gan, J.Y.; Wu, W.W. Thermal Stability and Performance of NbSiTaTiZr High-Entropy Alloy Barrier for Copper Metallization. J. Electrochem. Soc. 2011, 158, H1161-H1165. [CrossRef]

79. Yeh, A.C.; Tsao, T.K.; Chang, Y.J.; Chang, K.C.; Yeh, J.W.; Chiou, M.S.; Jian, S.R.; Kuo, C.M.; Wang, W.R.; Murakami, H. Developing New Type of High Temperature Alloys-High Entropy Superalloys. Int. J. Metall. Mater. Eng. 2015, 1, 107. [CrossRef]

80. Yeh, A.C.; Chang, Y.J.; Tsai, C.W.; Wang, Y.C.; Yeh, J.W.; Kuo, C.M. On the solidification and phase stability of a Co-Cr-Fe-Ni-Ti high-entropy alloy. Metall. Mater. Trans. A 2014, 45, 184-190. [CrossRef]

81. Chang, Y.J.; Yeh, A.C. The evolution of microstructures and high temperature properties of $\mathrm{Al}_{x} \mathrm{Co}_{1.5} \mathrm{CrFeNi}_{1.5} \mathrm{Ti}_{y}$ high entropy alloys. J. Alloys Compd. 2015, 653, 379-385. [CrossRef]

82. Tsao, T.K.; Yeh, A.C.; Kuo, C.M.; Murakami, H. High temperature oxidation and corrosion properties of high entropy superalloys. Entropy 2016, 18, 62. [CrossRef]

83. Daoud, H.M.; Manzoni, A.; Volkl, R.; Wanderka, N.; Glatzel, U. Microstructure and tensile behavior of $\mathrm{Al}_{8} \mathrm{Co}_{17} \mathrm{Cr}_{17} \mathrm{Cu}_{8} \mathrm{Fe}_{17} \mathrm{Ni}_{33}$ (at.\%) high-entropy alloy. JOM 2013, 65, 1805-1814. [CrossRef]

84. Manzoni, A.M.; Daoud, H.M.; Voelkl, R.; Glatzel, U.; Wanderka, N. Influence of W, Mo and Ti trace elements on the phase separation in $\mathrm{Al}_{8} \mathrm{Co}_{17} \mathrm{Cr}_{17} \mathrm{Cu}_{8} \mathrm{Fe}_{17} \mathrm{Ni}_{33}$ based high entropy alloy. Ultramicroscopy 2015, 159, 265-271. [CrossRef] [PubMed]

85. Daoud, H.M.; Manzoni, A.M.; Wanderka, N.; Glatzel, U. High-temperature tensile strength of $\mathrm{Al}_{10} \mathrm{Co}_{25} \mathrm{Cr}_{8} \mathrm{Fe}_{15} \mathrm{Ni}_{36} \mathrm{Ti}_{6}$ compositionally complex alloy (high-entropy alloy). JOM 2015, 67, 2271-2277. [CrossRef]

86. Manzoni, A.; Singh, S.; Daoud, H.; Popp, R.; Völkl, R.; Glatzel, U.; Wanderka, N. On the Path to Optimizing the Al-Co-Cr-Cu-Fe-Ni-Ti High Entropy Alloy Family for High Temperature Applications. Entropy 2016, 18, 104. [CrossRef]

87. Kao, Y.F.; Chen, S.K.; Sheu, J.H.; Lin, J.T.; Lin, W.E.; Yeh, J.W.; Lin, S.J.; Liou, T.H.; Wang, C.W. Hydrogen storage properties of multi-principal-component $\mathrm{CoFeMnTi}_{x} \mathrm{~V}_{y} \mathrm{Zr}_{z}$ alloys. Int. J. Hydrog. Energy 2010, 35, 9046-9059. [CrossRef]

88. Kunce, I.; Polanski, M.; Bystrzycki, J. Structure and hydrogen storage properties of a high entropy ZrTiVCrFeNi alloy synthesized using Laser Engineered Net Shaping (LENS). Int. J. Hydrog. Energy 2013, 38, 12180-12189. [CrossRef]

89. Zhang, Y.; Zuo, T.; Cheng, Y.; Liaw, P.K. High-entropy Alloys with High Saturation Magnetization, Electrical Resistivity, and Malleability. Sci. Rep. 2013, 3, 1455. [CrossRef] [PubMed] 
90. Tsai, M.H.; Yeh, J.W.; Gan, J.Y. Diffusion barrier properties of AlMoNbSiTaTiVZr high-entropy alloy layer between copper and silicon. Thin Solid Films 2008, 516, 5527-5530. [CrossRef]

91. Chang, S.Y.; Wang, C.Y.; Chen, M.K.; Li, C.E. Ru incorporation on marked enhancement of diffusion resistance of multi-component alloy barrier layers. J. Alloys Compd. 2011, 509, L85-L89. [CrossRef]

92. Chang, S.Y.; Chen, M.K. High thermal stability of AlCrTaTiZr nitride film as diffusion barrier for copper metallization. Thin Solid Films 2009, 517, 4961-4965. [CrossRef]

93. Shafeie, S.; Guo, S.; Hu, Q.; Fahlquist, H.; Erhart, P.; Palmqvist, A. High-entropy alloys as high-temperature thermoelectric materials. J. Appl. Phys. 2015, 118, 184905. [CrossRef]

94. Lai, C.H.; Lin, S.J.; Yeh, J.W.; Davison, A. Effect of substrate bias on the structure and properties of multi-element (AlCrTaTiZr)N coatings. J. Phys. D Appl. Phys. 2006, 39, 4628-4633. [CrossRef]

95. Huang, P.K.; Yeh, J.W. Inhibition of grain coarsening up to 1000 degrees $\mathrm{C}$ in (AlCrNbSiTiV)N superhard coatings. Scr. Mater. 2010, 62, 105-108. [CrossRef]

96. Cheng, K.H.; Tsai, C.W.; Lin, S.J.; Yeh, J.W. Effects of silicon content on the structure and mechanical properties of (AlCrTaTiZr)-Si $x_{x}-\mathrm{N}$ coatings by reactive RF magnetron sputtering. J. Phys. D Appl. Phys. 2011, 44, 205405. [CrossRef]

97. Qiu, X.W.; Liu, C.G. Microstructure and properties of $\mathrm{Al}_{2} \mathrm{CrFeCoCuTiNi}_{x}$ high-entropy alloys prepared by laser cladding. J. Alloys Compd. 2013, 553, 216-220. [CrossRef]

98. Shen, W.J.; Tsai, M.H.; Tsai, K.Y.; Juan, C.C.; Tsai, C.W.; Yeh, J.W.; Chang, Y.S. Superior Oxidation Resistance of $\left(\mathrm{Al}_{0.34} \mathrm{Cr}_{0.22} \mathrm{Nb}_{0.11} \mathrm{Si}_{0.11} \mathrm{Ti}_{0.22}\right)_{50} \mathrm{~N}_{50}$ High-Entropy Nitride. J. Electrochem. Soc. 2013, 160, C531-C535. [CrossRef]

99. Cantor, B.; Kim, K.B.; Warren, P.J. Novel multicomponent amorphous alloys. J. Metastab. Nanocryst. Mater. 2002, 13, 27-32. [CrossRef]

100. Kim, K.B.; Warren, P.J.; Cantor, B. Metallic glass formation in multicomponent (Ti, Zr, Hf, Nb)-(Ni, Cu, Ag)-Al alloys. J. Non-Cryst. Solids 2003, 317, 17-22. [CrossRef]

101. Kim, K.B.; Zhang, Y.; Warren, P.J.; Cantor, B. Crystallization behaviour in a new multicomponent $\mathrm{Ti}_{16.6} \mathrm{Zr}_{16.6} \mathrm{Hf}_{16.6} \mathrm{Ni}_{20} \mathrm{Cu}_{20} \mathrm{Al}_{10}$ metallic glass developed by the equiatomic substitution technique. Philos. Mag. 2003, 83, 2371-2381. [CrossRef]

102. Kim, K.B.; Warren, P.J.; Cantor, B. Formation of metallic glasses in novel $\left(\mathrm{Ti}_{33} \mathrm{Zr}_{33} \mathrm{Hf}_{33}\right)_{100-x-y}\left(\mathrm{Ni}_{50} \mathrm{Cu}_{50}\right)_{x} \mathrm{Al}_{y}$ alloys. Mater. Trans. 2003, 44, 411-413. [CrossRef]

103. Laws, K.J.; Crosby, C.; Sridhar, A.; Conway, P.; Koloadin, L.S.; Zhao, M.; Aron-Dine, S.; Bassman, L.C. High entropy brasses and bronzes-Microstructure, phase evolution and properties. J. Alloys Compd. 2015, 650, 949-961. [CrossRef]

104. Raabe, D.; Tasan, C.C.; Springer, H.; Bausch, M. From high-entropy alloys to high-entropy steels. Steel Res. Int. 2015, 86, 1127-1138. [CrossRef]

105. Pushin, V.G.; Kuranova, N.N.; Nikolaeva, N.V.; Uksusnikov, A.N.; Ustyugov, Y.M.; Belosludtseva, E.S.; Pushin, A.V.; Svirid, A.E. Specific features of the phase composition and structure of a high-strength multi-component Fe-W-Mo-Cr-V-Si-Mn-C steel synthesized via laser remelting. Adv. Eng. Mater. 2015, 17, 1504-1510. [CrossRef]

106. Wang, Y.P.; Li, D.Y.; Parent, L.; Tian, H. Improving the wear resistance of white cast iron using a new concept-High-entropy microstructure. Wear 2011, 271, 1623-1628. [CrossRef]

107. Zhang, Y.; Stocks, G.M.; Jin, K.; Lu, C.; Bei, H.; Sales, B.C.; Wang, L.; Beland, L.K.; Stoller, R.E.; Samolyuk, G.D.; et al. Influence of chemical disorder on energy dissipation and defect evolution in concentrated solid solution alloys. Nat. Commun. 2015, 6, 8736. [CrossRef] [PubMed]

108. Gludovatz, B.; Hohenwarter, A.; Catoor, D.; Chang, E.H.; George, E.P.; Ritchie, R.O. A fracture-resistant high-entropy alloy for cryogenic applications. Science 2014, 345, 1153-1158. [CrossRef] [PubMed]

109. Zhang, Z.; Mao, M.M.; Wang, J.; Gludovatz, B.; Zhang, Z.; Mao, S.X.; George, E.P.; Yu, Q.; Ritchie, R.O. Nanoscale origins of the damage tolerance of the high-entropy alloy CrMnFeCoNi. Nat. Commun. 2015, 6, 10143. [CrossRef] [PubMed]

110. Guo, S. Phase selection rules for cast high entropy alloys: An overview. Mater. Sci. Technol. 2015, 31, 1223-1230. [CrossRef]

111. Lu, Z.P.; Wang, H.; Chen, M.W.; Baker, I.; Yeh, J.W.; Liu, C.T.; Nieh, T.G. An assessment on the future development of high-entropy alloys: Summary from a recent workshop. Intermetallics 2015, 66, 67-76. [CrossRef] 
112. Shun, T.T.; Hung, C.H.; Lee, C.F. Formation of ordered/disordered nanoparticles in FCC high entropy alloys. J. Alloys Compd. 2010, 493, 105-109. [CrossRef]

113. Tsai, M.H.; Yuan, H.; Cheng, G.; Xu, W.; Jian, W.W.; Chuang, M.H.; Juan, C.C.; Yeh, A.C.; Lin, S.J.; Zhu, Y. Significant hardening due to the formation of a sigma phase matrix in a high entropy alloy. Intermetallics 2013, 33, 81-86. [CrossRef]

114. Chuang, M.H.; Tsai, M.H.; Wang, W.R.; Lin, S.J.; Yeh, J.W. Microstructure and wear behavior of $\mathrm{Al}_{x} \mathrm{Co}_{1.5} \mathrm{CrFeNi}_{1.5} \mathrm{Ti}_{y}$ high-entropy alloys. Acta Mater. 2011, 59, 6308-6317. [CrossRef]

115. Hsu, C.Y.; Juan, C.C.; Wang, W.R.; Sheu, T.S.; Yeh, J.W.; Chen, S.K. On the superior hot hardness and softening resistance of $\mathrm{AlCoCr}_{x} \mathrm{FeMo}_{0.5} \mathrm{Ni}$ high-entropy alloys. Mater. Sci. Eng. A 2011, 528, 3581-3588. [CrossRef]

116. He, J.Y.; Wang, H.; Huang, H.L.; Xu, X.D.; Chen, M.W.; Wu, Y.; Liu, X.J.; Nieh, T.G.; An, K.; Lu, Z.P. A precipitation-hardened high-entropy alloy with outstanding tensile properties. Acta Mater. 2016, 102, 187-196. [CrossRef]

117. Guo, N.N.; Wang, L.; Luo, L.S.; Li, X.Z.; Chen, R.R.; Su, Y.Q.; Guo, J.J.; Fu, H.Z. Effect of composing element on microstructure and mechanical properties in Mo-Nb-Hf-Zr-Ti multi-principle component alloys. Intermetallics 2016, 69, 13-20. [CrossRef]

118. Wani, I.S.; Bhattacharjee, T.; Sheikh, S.; Lu, Y.P.; Chatterjee, S.; Bhattacharjee, P.P.; Guo, S.; Tsuji, N. Ultrafine-grained $\mathrm{AlCoCrFeNi}{ }_{2.1}$ eutectic high-entropy alloy. Mater. Res. Lett. 2016. [CrossRef]

119. Tsai, M.H. High-Entropy Intermetallics-Pain or Opportunity? Presented at the 1st International Workshop on Microstructures and Mechanical Behavior of High-Entropy Alloys, Guiyang, China, 15-18 December 2014.

120. Tsai, M.H.; Fan, A.C.; Wang, H.A. Effect of atomic size difference on the type of major intermetallic phase in the $\mathrm{CoCrFeNiX}$ high-entropy alloys. In preparation.

121. Senkov, O.N.; Miller, J.D.; Miracle, D.B.; Woodward, C. Accelerated exploration of multi-principal element alloys with solid solution phases. Nat. Commun. 2015, 6, 6529. [CrossRef] [PubMed]

122. Senkov, O.N.; Miller, J.D.; Miracle, D.B.; Woodward, C. Accelerated exploration of multi-principal element alloys for structural applications. Calphad 2015, 50, 32-48. [CrossRef]

123. Gao, M.C.; Carney, C.S.; Doğan, Ö.N.; Jablonksi, P.D.; Hawk, J.A.; Alman, D.E. Design of Refractory High-Entropy Alloys. JOM 2015, 67, 2653-2669. [CrossRef]

124. Tsai, M.H.; Tsai, K.Y.; Tsai, C.W.; Lee, C.; Juan, C.C.; Yeh, J.W. Criterion for Sigma Phase Formation in Cr- and V-Containing High-Entropy Alloys. Mater. Res. Lett. 2013, 1, 207-212. [CrossRef]

125. Tsai, M.H.; Chang, K.C.; Li, J.H.; Tsai, R.C.; Cheng, A.H. A second criterion for sigma phase formation in high-entropy alloys. Mater. Res. Lett. 2016, 4, 90-95. [CrossRef]

126. Yurchenko, N.; Stepanov, N.; Salishchev, G. Laves-phase formation criterion for high-entropy alloys. Mater. Sci. Technol. 2016. [CrossRef]

127. Guo, S.; $\mathrm{Ng}$, C.; Liu, C.T. Anomalous solidification microstructures in Co-free $\mathrm{Al}_{x} \mathrm{CrCuFeNi}_{2}$ high-entropy alloys. J. Alloys Compd. 2013, 557, 77-81. [CrossRef]

128. Ng, C.; Guo, S.; Luan, J.; Wang, Q.; Lu, J.; Shi, S.; Liu, C.T. Phase stability and tensile properties of Co-free Al0.5CrCuFeNi2 high-entropy alloys. J. Alloys Compd. 2014, 584, 530-537. [CrossRef]

129. Murty, B.S.; Yeh, J.W.; Ranganathan, S. High-Entropy Alloys; Elsevier: Oxford, UK, 2014.

130. Gao, M.C.; Yeh, J.W.; Liaw, P.K.; Zhang, Y. High-Entropy Alloys: Fundamentals and Applications, 1st ed.; Springer International Publishing: Basel, Switzerland, 2016.

(C) 2016 by the author; licensee MDPI, Basel, Switzerland. This article is an open access article distributed under the terms and conditions of the Creative Commons Attribution (CC-BY) license (http://creativecommons.org/licenses/by/4.0/). 